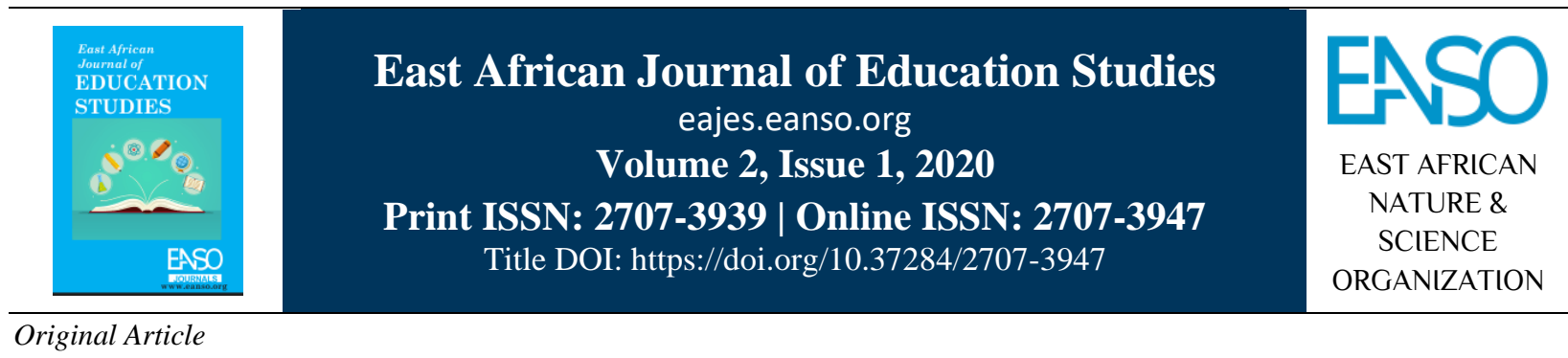

\title{
Influence of Constructivism Instructional Approach on Students' Achievement in Mathematics in Secondary Schools in Mandera Central Sub County, Kenya
}

\author{
Charles Ogembo Majiwa ${ }^{1, *}$, Dr. Benson Njoroge $e^{1} \&$ Dr. Nancy Cheseto ${ }^{1,2}$ \\ ${ }^{1}$ Mount Kenya University, P. O. Box 342-01000 Thika, Kenya. \\ * ORCID: http://orcid.org/0000-0030-1503-9779; Author for Correspondence Email: camenya201@ gmail.com. \\ ${ }^{2}$ ORCID: https://orcid.org/0000-0002-7013-320X.
}

Date Published: ABSTRACT

11 October 2020 Student's performance in Mathematics in national examinations has continued to be low. Efforts have been made to reverse this trend, but the low student

Keywords: performance persists. The situation is dire in Mandera Central Sub-County.

Perhaps it is imperative to investigate the influence of the constructivism Understanding,

Representation,

Constructivist Teaching

Approaches,

Traditional Teaching

Methods,

Learning Experience,

Self-Evaluation,

School Ethos.

instructional approach on student's achievement in mathematics in secondary schools, which is the main thrust of the current study. The objectives of the study were to examine the influence of explanation and elaboration on students' achievement in Mathematics in secondary schools in Mandera Central Subcounty, Kenya. The study was based on the concepts of individual constructivist theory, social constructivist theory and Jerome Brumer constructivist theory. The study used a mixed research methodology. The study adopted the experimental research design. The target population was a total of 2,573 respondents comprising of 120 teachers and 2,453 students from 3 boys' schools, 3 girls' schools and 3 mixed schools within Mandera Central Subcounty in Kenya. The sample of students to be used in the study was selected using random sampling procedures. The study sample size was 222 respondents. The validity of the instrument was ascertained by a panel of experts in Mathematics education from the Department of Education, Psychology and Technology, School of Education, Mount Kenya University. The data collected quantitatively was analysed by the use of descriptive statistics applying the use of SPSS (version 24) and its presentation was done by use of percentages, means, standard deviations and frequencies. The findings were displayed using bars, graphs, charts and in prose form. Content analysis was applied in testing the data that was qualitative in nature or aspect 
of the data that was gathered using open-ended questions. The findings showed that learners that were educated using the technique of constructivist had a higher achievement in Mathematics this is because there was a score in their achievement in Mathematics as compared to the students who were taught using the traditional approach. Additionally, those learners who were taught in a constructivist- learning environment had a significant in their understanding and their abilities in comparison to the rest of the improvement abilities such as knowledge and skills by $30 \%$. The study concluded that the constructivist method of teaching is suitable in bettering the achievement of learners in Mathematics and therefore needs to be embraced for practice for schools to realize improved performance in Mathematics.

\begin{abstract}
APA CITATION
Majiwa, C., Njoroge, B., \& Cheseto, N. (2020). Influence of Constructivism Instructional Approach on Students' Achievement in Mathematics in Secondary Schools in Mandera Central Sub County, Kenya. East African Journal of Education Studies, 2(1), 115-128. https://doi.org/10.37284/eajes.2.1.221.
\end{abstract}

\title{
CHICAGO CITATION
}

Majiwa, Charles, Benson Njoroge, and Nancy Cheseto. 2020. "Influence of Constructivism Instructional Approach on Students' Achievement in Mathematics in Secondary Schools in Mandera Central Sub County, Kenya". East African Journal of Education Studies 2 (1), 115-128. https://doi.org/10.37284/eajes.2.1.221.

\section{HARVARD CITATION}

Majiwa, C., Njoroge, B. and Cheseto, N. (2020) “Influence of Constructivism Instructional Approach on Students' Achievement in Mathematics in Secondary Schools in Mandera Central Sub County, Kenya", East African Journal of Education Studies, 2(1), pp. 115-128. doi: 10.37284/eajes.2.1.221.

\section{IEEE CITATION}

C. Majiwa, B. Njoroge, and N. Cheseto, “Influence of Constructivism Instructional Approach on Students' Achievement in Mathematics in Secondary Schools in Mandera Central Sub County, Kenya”, EAJES, vol. 2, no. 1, pp. 115-128, Oct. 2020.

\section{MLA CITATION}

Majiwa, Charles, Benson Njoroge, and Nancy Cheseto. "Influence of Constructivism Instructional Approach on Students' Achievement in Mathematics in Secondary Schools in Mandera Central Sub County, Kenya". East African Journal of Education Studies, Vol. 2, no. 1, Oct. 2020, pp. 115-128, doi:10.37284/eajes.2.1.221.

\section{INTRODUCTION}

The theory of constructivism is a theory developed recently and has become dominant and very significant in education (Taber, 2006). Bodner (1986) indicated that the focus of the constructivist model in constructing knowledge in the mind of learners. The learning experience of students differs and this makes it important for educators to know that the construction of knowledge is not the same in all learners. The pre-existing knowledge that students have is different depending on the past experience that is constructed in their mind (Taber, 2006). According to studies that have been done, the theory of constructivist is concerned with knowledge in the process of learning especially with its ability to address students' alternative understanding. Krishnan and Howe (1994) indicate that the difficulty of students in understanding science ideas because teachers do not have previous information on students understanding in class.

The role that is played by a teacher in a constructivist class is organizing situations that give the learner a chance of hypothesizing, predicting, manipulating, posing questions, research, investigating and inventing meanings. The centre of constructivism is the students whereby more value is placed on the students and not the teacher which implies that the learner is active. The learner is the one that relates the previously acquired knowledge with the new situations (Driver, 1995; Kibos, Wachanga \& Changeiywo, 2015). Through this, the researcher 
gains control over their learning (Brooks \& Brooks, 1993; Akar \& Yildirim, 2005). The students and the teacher work actively in a constructivist atmosphere (Akar \& Yildirim, 2005). The teacher gets to learn about the students and their learning process by asking questions, watching, and listening, this enables them to ensure that the students gain more and that the teacher is not just dispensing knowledge to them. This could also mean that the teacher acts as the researcher (Calkin, 1986). This form of learning does not emphasize on single answers and interpretation of a phenomenon in a single way. In coming up with hypotheses that are sophisticated, errors are very common but they are necessary. When they are learning, the students shouldn't be penalized when they take risks that result in errors but they should be helped patiently and also tolerated to eliminate the "errors" (Weaver, 1996). Before the teacher considers correcting the error made by the student, they should consider the impact it might have on the comprehension of the student regarding the idea that is being discussed. There is a high likelihood of achieving effective teaching when the students are involved more through dialogues and construction of meaning of significance to them (Wells \& Arauz, 2006).

Saudi Arabia had a national initiative of renewing the teaching and learning of Mathematics. Supervisors of education prepared a report which indicated that the techniques of teaching applied in Saudi classes were traditionally based and its main focus was memorizing and development of routine methods that were not successful in assisting students in developing clear comprehension and thinking of higher order. For the past 10 years, Saudi Arabia has witnessed a drastic decline in researches that have been carried out in the Mathematics field. The main key areas that were focused on in the researches were the improvement of teachers' pedagogies. This is because most of the Mathematics teachers used the approach that was centred on the teacher and not the student and therefore the students were not helped to engage in high order thinking (Bader, 2014; Alfarhod, 2009). Albalawi (2010) shed light on 8 key research areas in teaching and learning of Mathematics in Saudi to assist researchers to focus their researches on crucial areas needing research. The area that was of the highest priority was professional development for in-service Mathematics teachers.

The role that is played by mathematics in the real world is very important and the traditional ways of teaching cannot attain those goals put in place by schools. Experts in mathematics and interested parties have tried making proposals and solutions to techniques applied in teaching Mathematics and other problems in the curriculum and some of the proposals were workout and application of varying strategies and models based on modern teaching and theories of modern learning. The constructivist view of learning in the classroom could be pointed out to various practices of teaching. Usually, it implies encouraging the learner to apply the use of active methods (experiments, real-world problem solving) in creating more knowledge followed by reflecting on and talking about it and how it changes the way they understand. There is a need for the teacher to comprehend the pre-existing conception of students and guide the activity of addressing them and developing them.

According to research studies that have been conducted in Botswana on learning approach centred on students and the ones centred on the teacher have established that the most dominant approach is the one that is centred on the teacher (Prophet \& Rowell, 1993; Tabulawa, 1998). An example is a research that was carried out by on Pedagogical Classroom Practice by Tabulawa, (1998), which showed that learners have been established to be receiving knowledge passively implying that they do not get the opportunity to build their own understanding. In the year 1977, the Commission on Education indicated that it was a major concern in the education system of the country. The policy that was being applied made the teacher dominate in the class because they transmitted most of the information to the learners in an abstract manner and therefore the students had to memorize. The policy required changes in class practices to enable the students to grow through teaching and the learning process to be centred on the students.

Africa is faced with a challenge of poor performance in Mathematics and Science and this trend is worrying. This trend was one of the agendas in a meeting that was recently conducted in 
Johannesburg South Africa. The warning that was given by the delegates was that if the teaching of Mathematics was not bettered then the economy of the continent won't be able to meet the goals of Millennium Development (Kibos et al., 2015). They further indicated that despite the fact that the poor performance I Mathematics is historical, the limited interest of the learners to learn Mathematics is greatly attributed to the way it is being taught.

Mathematics leads in logic science since other sciences like Chemistry, Physics, Biology and Geography depend on it. It is considered a basis for social life and the exploration of the entire universe. In the Kenyan curriculum, Mathematics is one of the essentials. Despite its great importance, the performance of the subject in the national examinations is the poorest compared to the rest of the sciences. The result is that it interferes with the student's post-secondary placement because Mathematics is greatly emphasized as a key requirement. KNEC reports for the year 2008/2009, the majority of the students were not able to answer application questions that relate to main topics in Mathematics.

According to the report, questions on circle geometry which form 38\% of the Mathematics curriculum was the worst performed. Strengthening Mathematics and Science in Secondary Education (SMASSE) baseline survey of 2004 agrees with the KNEC report since they established that for the past decades, KCSE candidates have lacked competence in answering questions that relate to circles, chords and tangents and vectors (SMASSE, 2004). SMASSE INSET programmes for teachers of mathematics and science were implemented in the entire country. Through those two reports, the government was enlightened and therefore initiated programs to deal with the problem. Ranani (2014) indicated that the performance of Mathematics has been poor. Njoroge (2014) also criticized the poor performance in Mathematics despite it being a very important subject which is depended on as a key to turn the country into an industrialized nation by the year 2030 .
Table 1: Natural Mean Standard Score of Mathematics at KCSE (2012-2016)

\begin{tabular}{ll}
\hline Year & Mean score \\
\hline 2012 & 4.066 \\
2013 & 4.289 \\
2014 & 4.275 \\
2015 & 4.858 \\
2016 & 4.821 \\
\hline
\end{tabular}

Source: Ministry of Education (2018)

In Mandera Central Sub-County, in the year 2010, out of a total of 42 schools that sat for their KCSE, only 18 of the candidates were able to score a mean score of above 6.4 in Mathematics. The majority of the schools scored a mean grade of less than 4.5 (mean grade $\mathrm{D}+$ ) in Mathematics. This implies that in the year 2010, the mean grade for Mathematics for the majority of the schools was below $\mathrm{D}+$. These results were not any different in the year 2013. The report by the county education office showed that in the year 2013, the mean score for Mathematics in county schools for the entire country was 5.707625 .

Table 2: Natural Mean Standard Score of Mathematics at KCSE (2012-2016) Mandera Central Sub County

\begin{tabular}{ll}
\hline Year & Mean score \\
\hline 2012 & 1.632 \\
2013 & 2.011 \\
2014 & 2.394 \\
2015 & 2.502 \\
2016 & 2.785 \\
\hline
\end{tabular}

Source: Ministry of Education (2018)

The poor performance could be because of the poor methods of teaching the subject. Other factors that could be attributed to the poor performance include; culture, religion, attitudes of the girls and the instructional method used in Mathematics classrooms (Glover \& Law, 2002). Dewey (1972) agreed that the outcome of learning is a disparity in cognition and not reinforcing the behaviour has proposed by espoused that learning results from cognitive dissonance rather than a reinforcement of behaviour as proposed by behaviourist learning. 


\section{Statement of the Problem}

Student's performance in Mathematics in national examination has continued to be low. The situation is even worse at Mandera Central Sub-County where most of the learning institutions were not able to attain a mean score of 4.5 (mean grade $\mathrm{D}+$ ) at KCSE in 2010. In addition, the mean score for KCSE in the country in 2013 was 5.7. In Kenya, conventional methods of instruction dominate classroom practices. The Ministry of Education has many interventions to address the low performance in Mathematics. This includes; pedagogy through SMASSE program, provision of resources, employment of qualified Mathematics teachers among others but the low performance persists. If the current situation is not arrested the schools in Mandera Central Sub-County will continue to register poor grades in Mathematics.

The challenges of the use of constructivism instructional approach in Mandera are teachers' lack of dedication to implement constructivist teaching. Scarcity of allotted time to carry out active learning in greater depth is also a key factor. Besides, teachers lack of skill and knowledge to utilize constructivist teaching strategies and scarcity of learning materials, especially in the Mathematics department. No study has been carried out on the influence of the constructivism instructional approach on students in the achievement of Mathematics in secondary schools in Mandera central sub-county Kenya. This formed the basis of the current study.

The purpose of the study was to establish the influence of the constructivism instructional approach on students in the achievement of Mathematics in secondary schools in Mandera central sub-county Kenya.

The study was guided by the following objectives:

i. To determine the influence of explanation on students' achievement in Mathematics in secondary schools in Mandera central subcounty, Kenya.

ii. To evaluate the influence of elaboration on students' achievement in Mathematics in secondary schools in Mandera central subcounty, Kenya.

\section{Significance of the Study}

The study formed new knowledge on the influence of the constructivism instructional approach on students in the achievement of Mathematics in secondary schools in Mandera central sub-county Kenya. These findings may be used by the Ministry of Education to improve their workability within the education sector. It may enlighten the stakeholders on the best methodology to improve performance in Mathematics education. The study may address the present and future challenges that still require solutions.

The study may help the educators to improve their teaching method since a constructivist teacher motivates their students to continuously assess the way the activity helps them to acquire understanding. Through questioning and strategies, the learners in a constructivist classroom become "expert learners." Through this, they get tools that are ever-broadening for them to continue earning. With a class that is well planned, the learners are able to learn ways of learning.

The teachers would be able to gain greater insight because constructivism does modifications of the role they play, the teacher is responsible for assisting students to build their own knowledge and not just give them facts. A constructivist teacher gives tools like solving problems and learning that is based on enquiry whereby students formulate and test their own ideas, draw conclusions, make inferences and pool and convey their knowledge in a learning environment that is collaborative.

This study was important to the students because it may help them in improving their understanding as well as performance. Constructivism is responsible for transforming learners into active participants when they are learning and nor passive recipients of knowledge. With the guide of an educator, students build their own knowledge actively and not just mechanical ingestion of knowledge from the teacher or a book.

\section{EMPIRICAL LITERATURE}

\section{Explanation Strategy in Constructivism}

The stage of explanation assists learners to uncover ideas that surround what they are exploring. 
Learners need to have the opportunity of verbalizing their conceptual comprehension, of encountering new content materials or demonstrating new skills (Loughran, Berry \& Mulhall, 2012). At this stage, the educator is provided with the opportunity of introducing primary content material such as formal terms, definitions, and other content information. The student on the other hand is provided with the opportunity of identifying skills and behaviour with the aim of experiencing and discovering content that could be used in that particular context (Ergin, 2012).

\section{Elaboration Strategy in Constructivism}

The phase of elaboration is created to extend the conceptual comprehension of learners in areas of skills as well as behaviour. In the framework of constructivist, it is the role of the teacher to provide opportunities to the student to practice and refine their skills as well as behaviour in an authentic context (Gregory \& Chapman, 2012). Learners are also provided with multiple chances to deepen and broaden the base of their knowledge and integrate the knowledge into their conceptual understanding and actions in and out of class. The strategies allow the learner to spend time to explore and explain the process and reflect the various experiences through which they can synthesize information (Quinn et al., 2012).

\section{Theoretical Framework}

\section{Figure 1: Theoretical Framework}

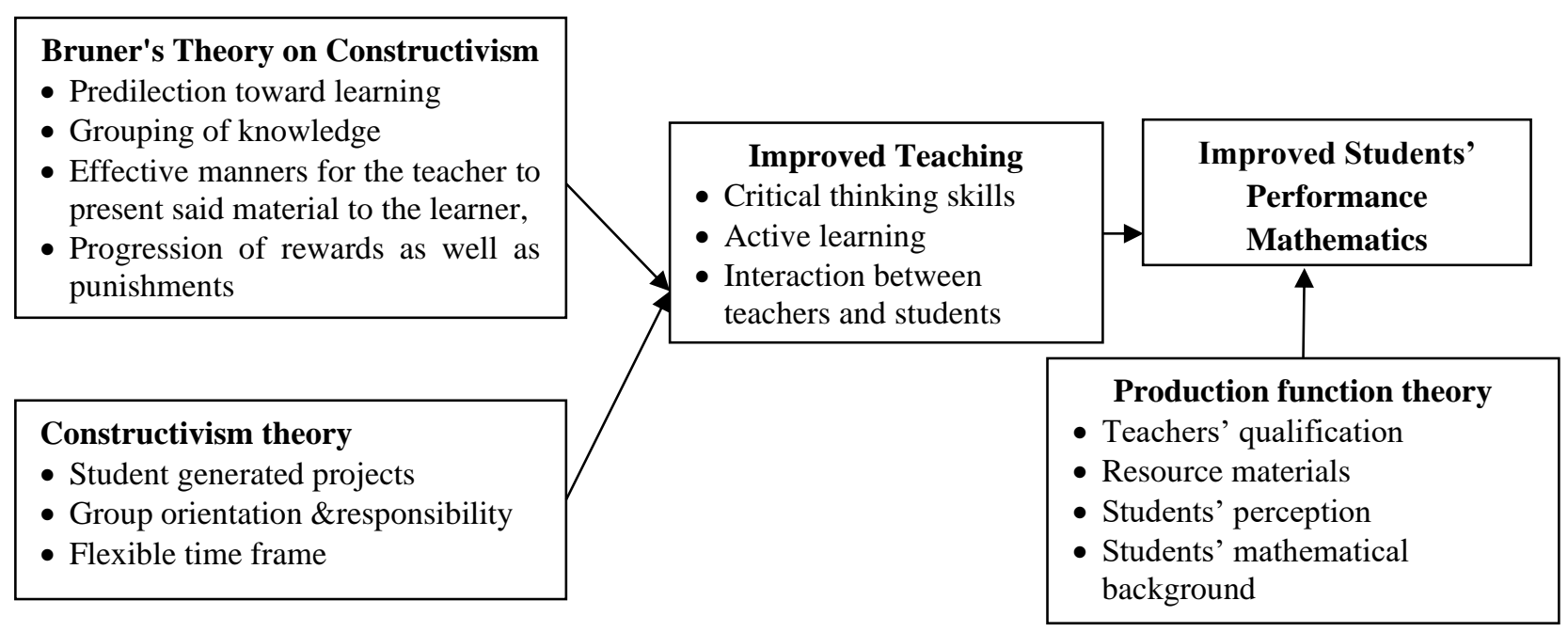

The basis of this study was the theory of constructivist learning whose origin was from the work of scientists who dealt with cognition such as Piaget and Dewey. The basis of constructivist teaching is the conviction that the process of learning takes place when the students are active in the process of constructing knowledge and meaning contrary to receiving information passively. This theory suggests that the students are the ones who make their knowledge and meaning. The advantage of Constructivist teaching is that it boosts critical and helps in creating students that are independent learners and motivated. According to this framework, learning is built upon the knowledge that the students already possess; and this knowledge that has been acquired previously is referred to as schema. Since the process of learning is filtered through already existing knowledge, the suggestion that is provided by constructivists is that the process of learning becomes more effective when the learners become actively engaged in the process of learning and not try to acquire knowledge passively. There are a number of techniques that claim that they are based on the theory of constructivist learning. The figure below diagrammatically represents an effective learning process as explained in the Constructivist theory of learning. The theory of Constructivist learning 
indicates that knowledge construction is based on schema. A child is not like a blank slate and therefore knowledge cannot be imparted to them without them making sense of it based on their current conception. This implies that a child can learn best when they are allowed to build their own comprehension depending on experience of things and reflections of the experiences. One key objective of applying constructivist when teaching is that it helps the learner to learns through training on how to take initiative for their personal learning processes.

\section{Conceptual Framework}

Figure 2: diagrammatically represents the conceptual Framework

\section{Independent variable}

\section{Constructivism Instructional Approach}

\section{Explanation Strategy \\ - Sharing of ideas \\ - Use of primary resources \\ Using own words to explain experiences}

\section{Dependent Variable}

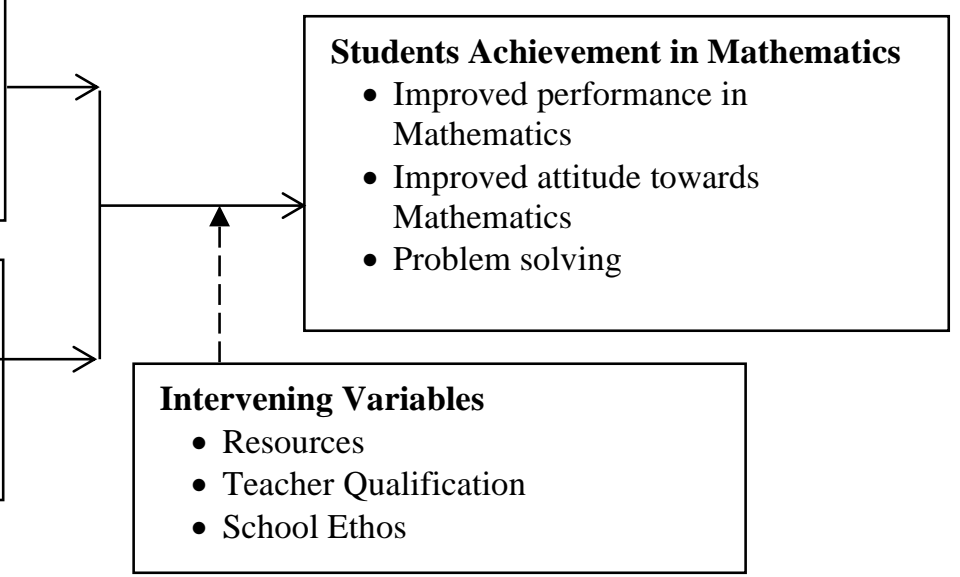

schools must ensure that they provide the needed resources, employ qualified teachers and building school ethos.

\section{RESEARCH METHODOLOGY}

The study applied the use of experimental research design. Experimental research designs are concerned with the examination of the effect of the independent variable on the dependent variable, where the independent variable is manipulated through treatment or intervention and the effect of those interventions is observed on the dependent variable (Kothari, 2014).

The research study was conducted in the subcounty of Mandera Central, Kenya. Mandera County located in North-Eastern part of Kenya and the county is made up of 5 sub-counties and Mandera central sub-county is one of them. 
The targeted population for this study was all students and teachers in selected secondary schools in Mandera Central Sub-County. According to the Mandera Central Sub-county education office, there are 9 schools in the Sub-County; 3 boys' schools, 3 girls' schools and 3 mixed schools within Mandera Central Sub-County in Kenya. Therefore, the target population was 2573 comprising of 2453 students and 120 teachers.

Table 3: Target Population

\begin{tabular}{llll}
\hline Category & F & $\begin{array}{l}\text { No. of } \\
\text { Students }\end{array}$ & $\begin{array}{l}\text { No. of } \\
\text { teachers }\end{array}$ \\
\hline $\begin{array}{l}\text { Boys' } \\
\text { Schools }\end{array}$ & 3 & 726 & 30 \\
$\begin{array}{l}\text { Girls' } \\
\text { School }\end{array}$ & 3 & 779 & 28 \\
$\begin{array}{l}\text { Mixed } \\
\text { Schools }\end{array}$ & 3 & 948 & 62 \\
Total & $\mathbf{9}$ & $\mathbf{2 4 5 3}$ & $\mathbf{1 2 0}$ \\
\hline
\end{tabular}

Source: Mandera Central Sub-County Education Office (2018)

The study was conducted in secondary schools that were selected in the sub-county. The study used random sampling procedures to select the students because they were a large number. Random sampling helped in selecting students in the institutions. The selected group was a representation of the entire population in which probability sampling was done. Random sampling was expected to produce the desired results. By using random sampling, it grouped the students accordingly in expounding on their involvement in class attendance and the general performance. The number of those who participated in the study is expected to be 222 comprising 207 students and 15 teachers.

Table 4: Sampling Grid

\begin{tabular}{lllll}
\hline Category & & F & $\begin{array}{l}\text { No. of } \\
\text { Students }\end{array}$ & $\begin{array}{l}\text { No. of } \\
\text { teachers }\end{array}$ \\
\hline Boys' & E & 1 & 36 & 3 \\
Schools & C & 1 & 28 & 2 \\
Girls' & E & 1 & 40 & 2 \\
School & C & 1 & 32 & 4 \\
Mixed & E & 1 & 41 & 2 \\
Schools & C & 1 & 30 & 2 \\
Total & & $\mathbf{6}$ & $\mathbf{2 0 7}$ & $\mathbf{1 5}$ \\
\hline
\end{tabular}

Key: E - Experiment group C - Control group

The study adopted the pre-test achievement tests to collect data. The design of Pre-test-post-test involves obtaining a pre-test measure of the result interested in before administration of treatments, then the post-test follows on the same measure after the occurrence of the treatment. The test was used in the research in order to ascertain whether the student groups to whom the application is performed are equal or not.

The study also used post-test assessments in data collection. The same participants are measured on the variables of interest at multiple points in time. Post-test was used with regards to display the effectiveness of the methods used in pre-tests.

Only form two students took the tests. There were no specific topics in the syllabus to be tested. The students who participated in the tests were expected to have been taught in three months that is a whole school term. The students in the control schools were taught the normal way while those in the experimental group were subjected to the test requirements. The expected score was at least 50 percent.

Data was collected from the teachers using questionnaires. A pilot study was conducted in order to establish the reliability and validity of the questionnaire in collecting the required data for the study. The data for this study were collected using a questionnaire; the data collection tool was tested to make sure that it was relevant and effective. The researcher piloted 8 questionnaires to a sample selected from the study population and they were not included in the actual study.

The data needed for the study was collected using pre-test/post-test assessments and questionnaires. This method was used because it provides both quantitative and qualitative data requirements. It has the advantage of encouraging high response rate providing data which is easy to organize tabulate and analyse statistically, which is the main objective of the study. Structured questionnaires were administered by trained and experienced teachers and experts in Mathematics educators.

The scores got from the tests were analysed in the SPSS-21 program. Unrelated samples t-test were 
used to measure the scores against each other using ANOVA and ANCOVA. Because of the superior power of the t-test in detecting the difference between two means, the study used it when dealing with two means. The difference between the posttest mean scores of the four groups was analysed using ANOVA. It was applied in determining if the difference is significant or not. ANCOVA was applied in establishing if there is an initial difference in the control and the initial groups. The experimental error is reduced statistically and not through experimental procedures (Borg \& Gall, 1989; Coolican, 1994).

The data collected quantitatively was analysed by the use of descriptive statistics applying the use of SPSS (Version 24) and its presentation was done by use of percentages, means, standard deviations and frequencies. The findings were displayed using bars, graphs, charts and in prose form. To achieve this, the responses were tallied, percentages of varied responses computed, description and interpretation of the data done based on the objectives of the study and assumptions. SPSS (Version 24) was applied in communicating the findings of the study. Content analysis was applied in testing the data that was qualitative in nature or aspect of the data that was gathered using openended questions.

\section{RESULTS AND DISCUSSION}

The sample that was selected for the study was 15 respondents out of which 14 dully filled and returned their questionnaires translating to a response rate of $93 \%$. According to Mugenda and Mugenda (2008), a rate of response of $50 \%$ is adequate; $60 \%$ is good and $70 \%$ and over is excellent (Mugenda \& Mugenda (2008). Therefore, our rate of response was excellent and suitable for analysis and reporting.

The first objective of the study was to determine the influence of explanation on students' achievement in Mathematics. The findings are presented in Table 5.

Table 5: Influence of Explanation on Students' Achievement in Mathematics

\begin{tabular}{lllllllll}
\hline Statements & & SD & D & M & A & SA & Mean & SD \\
\hline $\begin{array}{l}\text { Explanation describes the relevant occurrence, develops } \\
\text { the logical thinking of learner and guides the learner }\end{array}$ & $\mathrm{f}$ & 1 & 1 & 1 & 7 & 2 & 3.7 & 1.1 \\
through inductive judgment & & 7 & 7 & 7 & 64 & 14 & & \\
\hline $\begin{array}{l}\text { Explanation leads to clarifying interrelations, } \\
\text { demonstrating and justifying }\end{array}$ & $\mathrm{f}$ & 1 & 2 & 2 & 7 & 2 & 3.5 & 0.78 \\
\hline Explanation improves communication and reasoning & $\mathrm{f}$ & 7 & 14 & 14 & 50 & 14 & & \\
& $\%$ & 0 & 7 & 21 & 50 & 21 & 3.9 & 0.8 \\
\hline Explanation makes the meaning of an object clearer & $\mathrm{f}$ & 0 & 0 & 3 & 8 & 3 & 4.0 & 0.95 \\
& $\%$ & 0 & 0 & 21 & 57 & 21 & & \\
\hline
\end{tabular}

Table 5 the respondents agreed that explanation makes the meaning of an object clearer as shown by a mean of 4.0 and the standard deviation of 0.95 . Explanation improves communication and reasoning as shown by a mean of 3.9 and the standard deviation of 0.8. Explanation describes the relevant occurrence, develops the logical thinking of learner and guides the learner through inductive judgment as shown by a mean of 3.7 and the standard deviation of 1.1. In addition, explanation results to the clarification of interrelations, demonstrations and justification as shown by a mean of 3.5 and standard deviation of 0.78 . At the stage of explanation, learners get the chance of developing skills and behaviours that assist them in becoming successful learners. This implies that the explanation strategy improves students' achievement in Mathematics. The findings concur with Boud (2012) noted that learners also require experiences that assist them in developing new views and making a better sense of the world. This can be achieved through explanations in the classroom.

The second objective of the study was to evaluate the influence of elaboration strategy on students' achievement in Mathematics. 
East African Journal of Education Studies, Volume 2, Issue 1, 2020

Article DOI: https://doi.org/10.37284/eajes.2.1.221

Table 6: Influence of Elaboration on Students' Achievement in Mathematics

\begin{tabular}{|c|c|c|c|c|c|c|c|c|}
\hline Statements & & SD & D & $\mathbf{M}$ & $\mathbf{A}$ & SA & Mean & SD \\
\hline The elaboration helps students to comprehend new & $\mathrm{f}$ & 0 & 1 & 2 & 10 & 1 & 3.8 & 1.2 \\
\hline $\begin{array}{l}\text { information and establish how it's related to their } \\
\text { previously acquired information }\end{array}$ & $\%$ & 0 & 7 & 14 & 71 & 7 & & \\
\hline Organization of Mathematics content in line with & $\mathrm{f}$ & 1 & 1 & 1 & 6 & 5 & 3.9 & 0.9 \\
\hline $\begin{array}{l}\text { elaboration theory makes it compatible with knowledge } \\
\text { organization in the mind of the learners, which results in } \\
\text { the development of achievements academically and } \\
\text { critical thinking }\end{array}$ & $\%$ & 7 & 7 & 7 & 43 & 36 & & \\
\hline Through elaboration, learners are provided with analogies & $\mathrm{f}$ & 0 & 0 & 5 & 5 & 4 & 3.9 & 0.7 \\
\hline $\begin{array}{l}\text { that are familiar with the content of the lesson which eases } \\
\text { the learning process while reducing errors in the } \\
\text { understanding of knowledge }\end{array}$ & $\%$ & 0 & 0 & 36 & 36 & 29 & & \\
\hline The focus of elaboration is to link information with one & $\mathrm{f}$ & 0 & 2 & 2 & 6 & 4 & 3.9 & 0.8 \\
\hline $\begin{array}{l}\text { another assisting learners comprehend the association } \\
\text { between information and critical thinking like interpreting, } \\
\text { classifying, discriminating, deducting and concluding }\end{array}$ & $\%$ & 0 & 14 & 14 & 43 & 29 & & \\
\hline Learners are encouraged through elaboration to be the & f & 1 & 2 & 1 & 7 & 3 & 3.6 & 0.8 \\
\hline $\begin{array}{l}\text { central role in generating new course material with the } \\
\text { structure of already pre-existing knowledge. }\end{array}$ & $\%$ & 7 & 14 & 7 & 50 & 21 & & \\
\hline
\end{tabular}

Table 6 shows the respondents were in agreement that organization of Mathematics content in line with elaboration theory makes it compatible with knowledge organization in the mind of the learners, which results in the development of achievements academically and critical thinking as shown by a mean of 3.9 and standard deviation of 0.9. Through elaboration, learners are provided with analogies that are familiar with the content of the lesson which eases the learning process while reducing errors in the understanding of knowledge as shown by a mean of 3.9 and standard deviation of 0.8 . The focus of elaboration is to link information with one another assisting learners comprehend the association between information and critical thinking like interpreting, classifying, discriminating, deducting and concluding as shown by a mean of 3.9 and standard deviation of 0.8 . The elaboration helps students to comprehend new information and establish how it's related to their previously acquired information as shown by a mean of 3.9 and a standard deviation of 0.7 (see Table 6).
Learners are encouraged through elaboration to be the centre role in generating new course material with the structure of already pre-existing knowledge as shown by a mean of 3.6 (see Table 6). This shows that elaboration strategy facilitates the achievement of learners in Mathematics. These findings are in agreement with the findings of Baybee et al. (2006) that at the stage of elaboration learner needs to have the ability to apply concepts and skills in new but same situations and apply formal labels as well as definitions. The educator needs to remind the student of alternative explanations and considered the data existent and evident when exploring new situations.

With the aim of establishing the impact of the constructivist approach, data was analysed while considering the general achievement score of learners of Mathematics achievement test (MAT). The expected score was 50 percent. The post score of MAT was taken to help in analysing the difference in math achievement. 
East African Journal of Education Studies, Volume 2, Issue 1, 2020

Article DOI: https://doi.org/10.37284/eajes.2.1.221

Table 7: Pre-test Result on MAT Scores

\begin{tabular}{lllllc}
\hline Test & Groups & Mean & SD & df & t-value \\
\hline MAT & The experimental group $(\mathrm{N}=117)$ & 16.13 & 6.04 & & \\
& Control group $(\mathrm{N}=90)$ & 14.24 & 6.26 & 206 & 1.18 \\
\hline
\end{tabular}

Table 7 shows that the Mathematics achievement test of the experimental group was 16.13 and for the control group was 14.24 and the value of the standard deviation of the two groups was 6.04 and 6.26 respectively. The findings further revealed that the $\mathrm{t}$-value for MAT score was 1.18. At a 5\% level of significance, the t-value was less than the table value therefore there is no significant difference between the experimental group and the control group on MAT. Therefore, the two groups were revealed to be almost equal as far as past achievements in math were considered.

In order to establish the impact of the constructivist approach on learners' achievement in Mathematics, the study examined the post-test result on MAT scores for the two groups. The expected score was 50 percent. The findings were presented in Table 8.

Table 8: Post-Test Result on MAT Scores

\begin{tabular}{lllllll}
\hline Test & Groups & Mean & SD & df & t-value & P \\
\hline MAT & The experimental group $(\mathrm{N}=117)$ & 28.14 & 7.21 & 206 & 7.68 & \\
& Control group (N=90) & 19.36 & 8.05 & & & 0.001 \\
\hline
\end{tabular}

Table 8 revealed that the experimental group did achieve a greater mean score of 28.14 while the control scored a mean of 19.36. The performance of the experimental group outperformed that of the control group. The study applied a t-test to establish whether the two groups were different in MAT. At a significance level of 0.05 , ' $t$ ' value 7.68 is found to be statistically significant, which is an indication that there is a significant difference in MAT for the two groups in favour of the experimental group. Therefore, the hypothesis that learners taught using the constructivist method will perform significantly higher in Mathematics compared to the other group (control) was accepted. Therefore, the study concluded that the teaching and learning approach of constructivist improves the performance of learners in Mathematics in comparison to teaching and learning using the traditional techniques.

The achievement of learners who were assessed using the same MAT at the post-test might have been influenced to some level with pre-test exposure to MAT. This was controlled by applying ANCOVA. Taking of scores of the pre-test was as covariate and the post-test was the dependent variable. The findings were presented in Table 9.

Table 9: Analysis of Co-Variance for the Mathematics Achievement

\begin{tabular}{llllll}
\hline Score & Sum of squares & DF & Mean square & F-value & p \\
\hline Correlated model & 15162.65 & 2 & 7581.32 & 128.76 & \\
Intercept & 5731.53 & 1 & 5731.53 & 144.11 & \\
Co-variate (pre-test score) & 5867.36 & 1 & 5867.36 & 186.72 & 0.002 \\
Main effect (Treatment) & 4940.48 & 1 & 4940.48 & $122.63^{* *}$ & \\
Total correlated & 214611 & 116 & & & \\
\hline
\end{tabular}

Table 9 results show that the achievements of the experimental group that was exposed to the constructivist approach performed significantly higher compared to the control group who were exposed to the traditional ways of teaching $(\mathrm{p}<0.05$, $\mathrm{F}=122.63)$. Therefore, the constructivist technique improves the achievement of learners in
Mathematics compared to the traditional approach of teaching.

Learners require chances of addressing their previously acquired knowledge for them to tackle the misconceptions and develop concepts appropriately. In a class that is effective, learning 
needs more than the connection of new materials to old ways of thinking but rather it needs learners to come up with their own understanding. Learners have various ideas regarding various topics they are to encounter when going to school, some of them are incorrect while others are correct (Rutherford \& Ahlgren, 1990).

\section{CONCLUSION}

From the finding's explanation makes learning clearer hence, improving students' logical thinking. Explanation clarifies issues that may be at the students' mind hence justifying how a particular sum is done in a particular way. The study concludes that explanation is significant in providing detailed information hence essential in students' achievement in Mathematics.

From the findings, elaboration facilitates knowledge organization in the minds of the learners which results in the development of academic achievements and thinking critically. It also assists learners to be the centre point in the process of generation of their own course material using the knowledge that they already possess. The study concludes that elaboration is significant in improving students' achievement in Mathematics.

\section{RECOMMENDATIONS}

Based on the findings of the study, the study made the following recommendations

The study recommended that policymakers in the Ministry of Education should put into consideration encouraging Mathematics teachers to apply the use of the constructivist technique that used the 5Es (engagement, exploration, explanation, elaboration and evaluation) because this technique is very effective in learning Mathematics as compared to other conventional techniques that are applied currently by a majority of teachers.

So as to enhance performance in Mathematics, teachers need to consider applying the use of constructivist methods of teaching and this should as well be implemented in all secondary schools if achievement in Mathematics is to be realized. Since learner participation is important and has implications on performance, teachers should be able to adopt the constructivist instructional methods of instruction since it eliminates some of the classroom practices that do not encourage students to participate when learning Mathematics.

Finally, school administrators should be encouraged to improve on the management of academic programs by providing necessary facilities required for instructional purposes specifically a variety of text-books to promote constructivist methods of learning. These recommendations could be effectively implemented at the beginning of the Mathematics syllabus so as to improve the participation of the students as they have their first encounter with Mathematics in secondary school.

\section{AREA FOR FURTHER RESEARCH}

In this study constructivist method of instruction was delivered through the 5Es constructivist model with the use of pre-test and post-test methods of assessment to measure learning achievement. However, the study recommends further investigations into constructivist learning applying the use of other strategies of assessment other than the 5 Es.

\section{REFERENCES}

Akar, H. \& Yildrim, A. (2005). Use of constructive teaching activities in classroom management course: A research of action. Paper presented at the European Conference on Educational Research. University College Dublin.

Albalawi, A. (2010). Research priorities in the field of teaching and learning mathematics in Saudi Arabia. The Excellence Centre of Science and Mathematics Education. King Saud University.

Alfarhod, S. (2009). Teaching mathematics, the reality and expectations. The Journal of education and psychology: Saudi Association for Educational and Psychological, 6(2), 283308

Bader, B. (2014). Methods of teaching mathematics in girl's schools in Mecca and the extend of keep pace the modern age. The Journal of education and psychology: Saudi Association for Educational and Psychological, 3(4), 6689. 
Baybee, R., Tayler, J., Gadner, R., Scotter, P., \& Powell, J. West brook, A., \& Lardes, N. (2006). The BSCS 5E Instructional Model: Origins, effectiveness and applications. Executive Summary BSCS.

Bodner, G. (1986). Constructivism: A theory of knowledge. Journal of Chemical Education, 63(10), 873 - 878.

Borg, W. \& Gall M. (1989). Education research: An introduction ( $4^{\text {th }}$ ed.). New York.: Longman Inc.

Boud, D. (Ed.). (2012). Developing student autonomy in learning. Routledge.

Brooks, J. \& Brooks, M. (1993). In search of understanding: the case for constructivist classrooms. Alexandria: Association for Supervision and Curriculum Development.

Calkin, L. (1986). The art of teaching writing. Portsmith, NH: Heinemann

Coolican, H. (1994). Research methods in psychology (2nd Eds.). White Plains, NY: Longman

Dewey, J. (1972). Experience and education. New York, NY: Colloer Books.

Driver, R. (1995). Constructivist approaches in science teaching. In L.P. Steffe \& J. Gale (eds.). Constructivism in education (pp. 385 - 400). Hillsdale, NJ: Lawrence Erlbaum Associate.

Ergin, İ. (2012). Constructivist approach based 5E model and usability instructional physics. Latin-American Journal of Physics Education, 6(1), 322-367.

Glover, D. \& Law, S. (2002). Improving Learning: Professional practice in secondary schools. Philadelphia, USA: Open University Press.

Gregory, G. \& Chapman, C. (2012). Differentiated instructional strategies: One size doesn't fit all. London: Corwin Press.

Kibos, R. C., Wachanga, S. W., \& Changeiywo, J. M. (2015). Effects of Constructivist Teaching Approach on Students' Achievement in
Secondary School Chemistry in Baringo North Sub-County, Kenya. International Journal of Advanced Research, 3(7), 1037-1049.

Kothari, C.R. (2014). Research Methodology, Third Edition, New. Age International Publishers, New Delhi.

Krishnan, S. \& Howe, A. (1994). The mole concept. Developing an instrument to assess conceptual understanding. Journal of Chemical Education, $7(8), 653-656$.

Loughran, J., Berry, A., \& Mulhall, P. (2012). Understanding and Developing Science Teachers' Pedagogical Content Knowledge (Vol. 12). Springer Science \& Business Media.

Ministry of Education (2018). KCSE Mathematics Score 2012-2016. Retrieved from MoE.Co.Ke

Mugenda, O. \& Mugenda, A. (2003). Research methods: Quantitative and qualitative Approaches. Nairobi: African Centre for Technology Studies.

Njoroge, M. (2014). Causes of poor Mathematics performance in Thika County. International, Journal of Education and Practice, 5(35).

Piaget, J. (1954). Construction of reality in the child. New York: Basic Books, Inc.

Prophet, R. B., \& Rowell, P. M. (1993). Coping and control: Science teaching strategies in Botswana. International Journal of Qualitative Studies in Education, 6(3), 197-209.

Quinn, D., Amer, Y., Lonie, A., Blackmore, K., Thompson, L., \& Pettigrove, M. (2012). Leading change: Applying change management approaches to engage students in blended learning. Australasian Journal of Educational Technology, 28(1), 16-29.

Ranani, O. (2014). Methods of improving Mathematics performance in Muranga County. Journal of Creative Ideas, 4(8).

Rutherford, F. \& Ahlgren, A. (1990). Science for All Americans. Washington, DC: American Association for the Advancement of Science 
SMASSE Baseline survey (2004). Strengthening mathematics and science in Secondary Education, Science and Technology, Republic of Kenya. Retrieved from http://www.Smasse.org.

Taber, K. (2006). Beyond constructivism: the progressive research programme into learning science. Studies in science education, 42(2), $125-180$.

Tabulawa, R. (1998). Teachers' perspectives on classroom practice in Botswana: Implications for pedagogical change. International Journal of Qualitative Studies in Education, 11(2), 24968.

Weaver, C. (1996). Teaching grammar in the context of writing. The English Journal, 85(7), $15-24$.

Wells, G., \& Arauz, R. M. (2006). Dialogue in the classroom. The journal of the learning sciences, 15(3), 379-428. 